\title{
Axillary nerve palsy following blunt trauma to the shoulder region: a clinical and electrophysiological review
}

\author{
HENRY BERRY, VERA BRIL
}

From the Department of Neurology, St Michael's Hospital, University of Toronto, Ontario, Canada.

SUMMARY Although the commonest type of axillary nerve palsy occurs following shoulder dislocation on humeral fracture, another form is seen after blunt trauma to the shoulder region without associated fracture or dislocation. The former usually goes on to a full recovery whereas a failure to recover is common in the latter group. In our review of 13 patients with palsy after blunt shoulder trauma, seven patients showed minimal or no recovery of deltoid muscle function and six patients went on to complete or near complete recovery. Serial electromyographic examinations usually revealed the lesion to be in continuity although eventual clinical recovery was not satisfactory in a number of these patients. The mechanism of the palsy appeared to involve a stretch injury and this was confirmed at operation in two patients. Glenohumeral fixation was a troublesome complication which limited recovery of function in four patients. Further details of the type of trauma, clinical and electromyographic examination, assessment and management are discussed.

Axillary nerve palsy is commonly due to trauma although it represents less than $1 \%$ of nerve injuries. ${ }^{12}$ In the large series of peripheral nerve injuries arising out of wartime experience, only five out of a total of 4000 cases were described by Frazier and Silbert ${ }^{3}$ and 25 out of 2636 cases by Bristow. ${ }^{4}$ In these reports, the nature of the trauma whether blunt, penetrating or associated with fracture or dislocation of the humerus was not specified. More recently, Blom and Dahlback, ${ }^{5}$ in their inquiry into the incidence of this condition with fracture dislocation of the humerus, found clinical and/or electromyographic evidence of axillary nerve palsy, usually mild in degree, in 26 out of 73 patients. Leffert and Seddon ${ }^{6}$ found clinical evidence of axillary nerve involvement in 13 patients who had suffered dislocation or fracture of the surgical neck of the humerus and a larger group of 31 patients with infraclavicular brachial plexus lesions. A review of these published studies reveals some disagreement as

Address for reprint requests: Dr H Berry, Department of Neurology, St Michael's Hospital, 30 Bond Street, Toronto, Ontario, M5B 1W8, Canada

Received 24 February 1982 and in revised form 4 August 1982 Accepted 20 August 1982 to prognosis and management. Leffert and Seddon ${ }^{6}$ reported that none of the patients with isolated axillary palsy went on to full recovery although those in whom there was an associated posterior cord lesion had a better prognosis. Sunderland ${ }^{7}$ stated that most cases of axillary nerve palsy recover spontaneously although there may be a delay of up to 12 months. Blom and Dahlback ${ }^{5}$ describe spontaneous and satisfactory recovery over 3 to 5 months in all of their patients; they also stated that surgical exploration was not indicated as the recovery was satisfactory in those patients with complete initial paralysis or denervation.

The axillary nerve does not appear to be involved as a form of mononeuritis in diabetes or collagen vascular disease. Spontaneous involvement does occur, however, in neuralgic amyotrophy. ${ }^{89}$ Deltoid muscle paralysis, with or without sensory involvement, occurs alone in about $50 \%$ of such patients, and there is associated involvement of adjacent muscles in about half of these patients. Kirby and $\mathrm{Kraft}^{10}$ have described a case which they interpreted to be an entrapment neuropathy of the anterior branch of the axillary nerve by hypertrophied muscles in the quadrangular space in a paraplegic patient, but entrapment has not been a 
feature in other reported cases.

The older tests of electrical reaction were used in earlier studies and it is only in the study of Blom and Dahlback ${ }^{5}$ that electromyography has been utilised to establish minimal or subclinical involvement, partial or complete denervation and evidence of recovery. Most authors $^{5-71112}$ describe axillary nerve palsy as a complication of shoulder dislocation or fracture of the surgical neck of the humerus. We have encountered a number of patients in whom the palsy developed following blunt trauma to the shoulder region, without fracture or dislocation. We review the clinical and electromyographic findings, and the management and eventual outcome of these patients.

\section{Method}

\section{Patients}

The series is of 13 patients with axillary nerve palsy out of a total of 4134 patients referred for electrophysiologic examination to the electrophysiology laboratory of a large urban general hospital between the years 1967 and 1978 . The referrals had come from orthopaedic and neurosurgical services, or the Workmen's Compensation Board. Those with palsy associated with shoulder dislocation and two patients with axillary palsy as a complication ol local surgical exploration, were excluded from this review. Each of the 13 patients had suffered blunt trauma to the shoulder region without fracture, dislocation or evidence of penetrating injury. All were male, aged 18 to 60 with a mean of 37 years. All patients were first examined 1 to 6 months after the onset of paralysis and 11 were seen in one or more follow-up examinations. Neurological examination for muscle atrophy, weakness and sensory impairment was done in all patients and muscle weakness was graded on the MRC scale.

\section{Electrophysiologic assessment}

Electromyographic examination of the deltoid muscle, with a concentric needle electrode, was done in all patients and adjacent muscles were sampled when this was indicated. The presence of surviving motor units, the completeness of the interference pattern, evidence of denervation and of re-innervation, were noted. The degree of severity of the electromyographic findings was classified as follows: normal, without denervation, numerous motor units under voluntary control and a full interference pattern; mild, with denervation, diminished motor units under voluntary control, mild decrease in interference pattern; moderate, with denervation, a few surviving motor units or nascent potentials in the recovery stage, marked reduction in interference pattern; complete, with denervation, absence of motor units under voluntary control and a complete loss of interference pattern.

\section{Results}

A summary of the entire series is given in table 1. All patients had suffered blunt trauma to the shoulder region; in four, a heavy object such as the limb of a tree, cement slab or debris in an accidental cave-in, were involved. In seven patients, the blow occurred at the time of a fall or in a motor vehicle accident. The palsy developed after a boxing bout in one patient and in another, it occurred after the upper limb had been caught in the moving mechanism of a gravel crusher; an element of traction may have been involved in these two patients. In two patients (cases 5 and 13), the onset was delayed and the paralysis was first noticed 12 to 24 hours after a fall from a motor cycle and a boxing bout respectively; neither event had involved any disturbance of consciousness.

In most the trauma was of limited severity and appeared to be localised to the shoulder region. Three patients had been involved in motor cycle accidents with more severe trauma with head injury, coma, fractures of the extremities and spinal cord injury in one. In five patients, axillary nerve palsy was associated with an involvement of one or more of the other nerves in the shoulder region; in four, there was suprascapular nerve involvement usually partial in degree. One patient had a partial radial nerve palsy above the level of the spiral groove with a degree of triceps paralysis in association with a complete axillary nerve palsy. Two patients had involvement of other nerves well outside the shoulder region as evidence of more severe trauma and these details are not contained in the summary; one had a traumatic median and ulnar nerve palsy at the forearm level in the contralateral arm; one patient had a sciatic nerve palsy in relation to a fracture of the shaft of the femur and another developed an incomplete pressure palsy of the ipsilateral radial nerve during his hospital stay.

Follow-up examinations were done in 11 patients; two patients were not followed although one of these had only a mild degree of involvement. Of the remainder, five were examined on two occasions, three on three occasions and three on four occasions. The degree of recovery was assessed according to the following scale: good-full strength or minimal residual weakness; moderate-intermediate weakness; poor-minimal or no power.

It is of interest that sensory loss was present in only nine patients. A restriction of shoulder movement on the basis of glenohumeral joint fixation was a complication in four patients; in two of these, the degree of axillary nerve palsy was relatively mild and in the remaining two, it was more severe. In two of these patients with this complication, the clinical picture continued to be dominated by pain and limited movement in spite of nerve recovery. Furthermore, it appeared that psychological factors with over-reaction, guarding and limitation of movement had played a role in the development of glenohumeral fixation and in the incomplete recovery. 
Table 1 Summary of 13 patients with axillary nerve palsy after blunt trauma

\begin{tabular}{|c|c|c|c|c|c|c|c|c|c|c|}
\hline $\begin{array}{l}\text { Patient } \\
\text { no. }\end{array}$ & $\begin{array}{l}\text { Age } \\
(y r)\end{array}$ & Sex & Type of trauma & $\begin{array}{l}\text { Time of } \\
\text { assessment } \\
\text { after onset } \\
(m, y r)\end{array}$ & $\begin{array}{l}\text { Degree of } \\
\text { motor } \\
\text { function } \\
(M R C \\
\text { scale) }\end{array}$ & $\begin{array}{l}\text { Sensory } \\
\text { involvement }\end{array}$ & $\begin{array}{l}\text { EMG results } \\
\text { (degree of } \\
\text { paralysis and } \\
\text { denervation) }\end{array}$ & $\begin{array}{l}\text { Regional } \\
\text { nerve } \\
\text { involvement }\end{array}$ & $\begin{array}{l}\text { Associated } \\
\text { complications }\end{array}$ & $\begin{array}{l}\text { Course and } \\
\text { degree of } \\
\text { recovery }\end{array}$ \\
\hline 1 & 55 & $\mathbf{M}$ & Fell on shoulder & $1 \mathrm{~m}$ & 4 & yes & mild & none & $\begin{array}{l}\text { glenohumeral } \\
\text { fixation }\end{array}$ & \\
\hline 2 & 39 & $\mathbf{M}$ & $\begin{array}{l}\text { Soil and debris } \\
\text { fell on shoulder }\end{array}$ & $\begin{array}{l}3 \mathrm{~m} \\
2 \cdot 5 \mathrm{~m}\end{array}$ & $\begin{array}{l}5 \\
0\end{array}$ & yes. & $\begin{array}{l}\text { normal } \\
\text { complete }\end{array}$ & none & none & good \\
\hline & & & & $\begin{array}{l}5.5 \mathrm{~m} \\
7.5 \mathrm{~m}\end{array}$ & $\begin{array}{l}0 \\
1\end{array}$ & & moderate & & $\begin{array}{l}\text { none } \\
\text { none }\end{array}$ & poor \\
\hline 3 & 19 & $\mathbf{M}$ & $\begin{array}{l}\text { Motorcycle } \\
\text { accident-coma }\end{array}$ & $2 \mathrm{~m}$ & 0 & yes & complete & none & none & not known \\
\hline 4 & 39 & $\mathbf{M}$ & $\begin{array}{l}\text { Cement slab fell } \\
\text { on shoulder }\end{array}$ & $\begin{array}{r}3 \mathrm{~m} \\
4 \mathrm{~m} \\
6 \mathrm{~m} \\
11 \mathrm{~m}\end{array}$ & $\begin{array}{l}0 \\
0 \\
2 \\
2\end{array}$ & yes & $\begin{array}{l}\text { moderate } \\
\text { moderate } \\
\text { mild }\end{array}$ & none & $\begin{array}{l}\text { glenohumeral } \\
\text { fixation with } \\
\text { severe pain }\end{array}$ & poor \\
\hline 5 & 18 & $\mathbf{M}$ & $\begin{array}{l}\text { Fell off } \\
\text { motorcycle- } \\
\text { arm weak } \\
\text { next morning }\end{array}$ & $8 \mathrm{~m}$ & 0 & yes & complete & none & $\begin{array}{l}\text { none } \\
\text { none }\end{array}$ & $\begin{array}{l}\text { sural graft } \\
\text { at } 6 \mathrm{~m} \text {; } \\
\text { poor }\end{array}$ \\
\hline 6 & 57 & $\mathbf{M}$ & $\begin{array}{l}\text { Fell and hit } \\
\text { shoulder }\end{array}$ & $5 \mathrm{~m}$ & 0 & yes & complete & none & none & $\begin{array}{l}\text { neurolysis } \\
\text { at } 5 \mathrm{~m} \text {; } \\
\text { poor }\end{array}$ \\
\hline 7 & 21 & $\mathbf{M}$ & $\begin{array}{l}\text { Motorcycle } \\
\text { accident-- } \\
\text { coma; multiple } \\
\text { fractures and } \\
\text { paraplegia }\end{array}$ & $\begin{array}{l}3 \mathrm{~m} \\
5 \mathrm{~m} \\
6 \mathrm{~m} \\
7 \mathrm{~m}\end{array}$ & $\begin{array}{l}0 \\
0 \\
0 \\
2 \\
4\end{array}$ & no & $\begin{array}{l}\text { complete } \\
\text { moderate } \\
\text { moderate } \\
\text { mild }\end{array}$ & none & $\begin{array}{l}\text { none } \\
\text { none } \\
\text { none } \\
\text { none }\end{array}$ & good \\
\hline 8 & 60 & $\mathbf{M}$ & $\begin{array}{l}\text { Tree fell on } \\
\text { patient }\end{array}$ & $\begin{array}{l}4 \mathrm{~m} \\
7 \mathrm{~m}\end{array}$ & $\begin{array}{l}0 \\
0\end{array}$ & yes & $\begin{array}{l}\text { complete } \\
\text { moderate }\end{array}$ & none & none & poor \\
\hline 9 & 48 & $\mathbf{M}$ & $\begin{array}{l}\text { Tree limb fell } \\
\text { on patient }\end{array}$ & $\begin{array}{l}5 \mathrm{~m} \\
6 \mathrm{~m} \\
10 \mathrm{~m}\end{array}$ & $\begin{array}{l}0 \\
2\end{array}$ & yes & $\begin{array}{l}\text { complete } \\
\text { moderate } \\
\text { moderate }\end{array}$ & $\begin{array}{l}\text { radial } \\
\text { (incomplete) }\end{array}$ & $\begin{array}{l}\text { glenohumeral } \\
\text { fixation } \\
\text { glenohumeral } \\
\text { fixation }\end{array}$ & poor \\
\hline 10 & 42 & $\mathbf{M}$ & $\begin{array}{l}\text { Hit car } \\
\text { dashboard } \\
\text { with } \\
\text { shoulder }\end{array}$ & $\begin{array}{r}6 \mathrm{~m} \\
10 \mathrm{~m} \\
1 \mathrm{yr} \\
9 \mathrm{yr}\end{array}$ & $\begin{array}{l}3 \\
4 \\
5\end{array}$ & no & $\begin{array}{l}\text { mild } \\
\text { mild } \\
\text { mild } \\
\text { mild }\end{array}$ & $\begin{array}{l}\text { supra- } \\
\text { scapular } \\
\text { (incomplete) }\end{array}$ & $\begin{array}{l}\text { none } \\
\text { none } \\
\text { none } \\
\text { none }\end{array}$ & good \\
\hline 11 & 18 & $\mathbf{M}$ & $\begin{array}{l}\text { Motorcycle } \\
\text { accident- } \\
\text { coma: femoral }\end{array}$ & $1.5 \mathrm{~m}$ & 0 & no & complete & $\begin{array}{l}\text { supra- } \\
\text { scapular }\end{array}$ & none & \\
\hline 12 & 41 & $\mathbf{M}$ & $\begin{array}{l}\text { coma; femoral } \\
\text { fracture } \\
\text { Arm pulled } \\
\text { into gravel } \\
\text { crusher }\end{array}$ & $\begin{array}{l}2.5 \mathrm{~m} \\
6.5 \mathrm{~m} \\
3 \mathrm{~m}\end{array}$ & $\begin{array}{l}0 \\
5 \\
4\end{array}$ & no & $\begin{array}{l}\text { moderate } \\
\text { mild }\end{array}$ & $\begin{array}{l}\text { (incomplete) } \\
\text { supra- } \\
\text { scapular } \\
\text { (incomplete) }\end{array}$ & $\begin{array}{l}\text { none } \\
\text { none } \\
\text { glenohumeral } \\
\text { fixation } \\
\text { with severe } \\
\text { pain }\end{array}$ & good \\
\hline 13 & 19 & $\mathbf{M}$ & $\begin{array}{l}\text { Boxing match; } \\
\text { arm weak next } \\
\text { day }\end{array}$ & $\begin{array}{l}6 \mathrm{yr} \\
5 \mathrm{~m}\end{array}$ & $\begin{array}{l}4 \\
2\end{array}$ & yes & mild & $\begin{array}{l}\text { supra- } \\
\text { scapular } \\
\text { (complete) }\end{array}$ & none & $\begin{array}{l}\text { good } \\
\text { not known } \\
\text { (mild initial } \\
\text { involvement) }\end{array}$ \\
\hline
\end{tabular}

Two of the patients with complete palsy underwent surgical exploration at 5 and 6 months respectively. In one, the nerve was in discontinuity and an end bulb, about the size of a pea, $1 \mathrm{~cm}$ distal to the origin of the axillary nerve from the posterior cord, was identified. A gap of $2 \mathrm{~cm}$, with intervening fibrous strands, was present between this swelling and the end of the distal portion of the nerve. There was considerable scar formation in the quadrangular space and the appearance was that of a severe stretch injury. A sural nerve graft was done with the use of the operating microscope and an interfascicular graft technique. Two months post-operatively there was no clinical evidence of recovery although EMG examination was not done. In the other patient, scar formation was also considerable; the nerve was in continuity but was attenuated throughout its course and the appearance was that of an atrophic nerve. An external neurolysis was done and the epineurium was opened in order to verify continuity of the fascicular pattern. Clinical examination at 5 months after this procedure has not revealed any recovery.

Table 2 compares the severity of clinical paralysis in 12 patients at the time of initial examination with the degree of recovery as determined by follow-up or as could be predicted in the one patient who had mild weakness at the time of his initial and only examination. Eight patients had complete paralysis 
Table 2 Relationship between paralysis and recovery in 12 patients

\begin{tabular}{llll}
\hline $\begin{array}{l}\text { Initial paralysis } \\
\text { (MRC grade) }\end{array}$ & No of patients & $\begin{array}{l}\text { Final strength } \\
\text { (MRC grade) }\end{array}$ & No of patients \\
\hline 0 & 8 & 0 & 3 \\
& & 1 & 1 \\
& & 2 & 2 \\
& 4 & 1 \\
2 & $1^{*}$ & 5 & 1 \\
3 & 1 & 5 & 1 \\
4 & 2 & 4 & 1 \\
& & 5 & 1 \\
\hline
\end{tabular}

*Patient was seen once and had mild electrical involvement.

by clinical and electromyographic criteria and there was marked muscle atrophy. Two patients were seen between 5 and 6 months after onset and were found to have a complete paralysis on clinical and electromyographic examination. Because of the absence of recovery after this time interval, they underwent surgical exploration as previously noted. In one patient, nascent polyphasic potentials were detected $2 \frac{1}{2}$ months after onset and after a further $4 \frac{1}{2}$ months, the deltoid muscle had recovered full power. In another, nascent potentials were not detected until the fifth month and the patient developed grade 4 power during the seventh month. Two patients with complete paralysis were followed for 7 months and one for 11 months after onset; an increasing number of motor units under voluntary control were demonstrated, albeit with only minimal return of muscle power. As it would be reasonable to predict, the patients with the lesser degree of involvement had a better outcome than those with severe or complete paralysis. In this small series therefore, only two patients out of the group of eight with complete initial paralysis, went on to a good recovery.

\section{Discussion}

\section{DIFFERENTIAL DIAGNOSIS}

The diagnosis is readily made as there is a clear relationship to trauma. Paralysis is localised to the deltoid muscle without involvement of the adjacent muscles of $\mathrm{C} 5$ segmental origin and this combination of findings tends to exclude a more proximal or root lesion. Painful paralysis, sudden in onset, of the deltoid and adjacent muscles is a feature of neuralgic amyotrophy or localised shoulder neuritis ${ }^{89}$ and the paralysis is isolated to the deltoid muscle in about $50 \%$ of patients; in the remainder, there is involvement of the serratus anterior, spinati as well as the deltoid and other muscles. In any event, neuralgic amyotrophy is of spontaneous origin and is not a con- sideration in patients who have suffered trauma to the shoulder region. The condition occurs in patients who have either suffered a fall, in whom a heavy object has fallen on the shoulder without serious injury, or in those who have been involved in a motor vehicle accident with unconsciousness and more serious injuries. The initial paralysis is complete in more than half of patients and recovery is minimal or absent in about one half. This observation contrasts with the finding of partial paralysis and good prognosis noted by Sunderland ${ }^{7}$ and Blom and Dahlback. ${ }^{5}$

\section{ANATOMICAL CONSIDERATIONS}

The normal anatomical relationships of the axillary nerve are shown in fig 1 . The axillary nerve arises from the lateral aspect of the posterior cord, descends on the anterior aspect of the subscapularis muscle and passes dorsally through the quadrangular space at the lower border of the subscapularis muscle with the capsule of the joint superiorly, the surgical neck of the humerus laterally, the long head of triceps medially and the teres major muscle below. When the nerve leaves this space, it is deep to the deltoid muscle and it divides into two terminal divisions; the anterior division is longer, winds around the surgical neck of the humerus and is then applied and attached to the

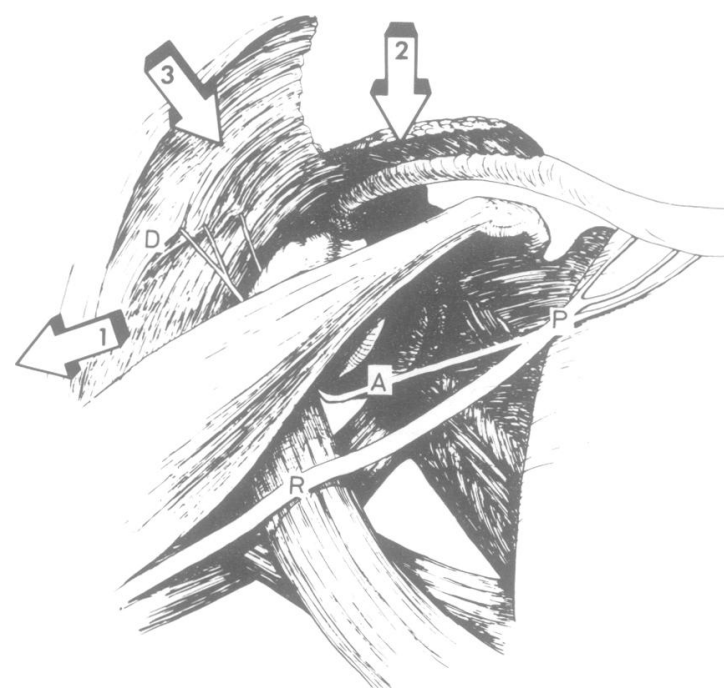

Fig 1 The normal anatomical relationships of the axillary nerve. The posterior cord $P$ divides into the axillary nerve $A$ and the radial nerve $R$. The anterior and posterior divisions of the axillary nerve enter the deltoid muscle $D$. The head of the humerus is in a normal position. In blunt trauma without dislocation or fracture, the common directions of the force, in order of frequency, were downward and outward (1), downward (2) and downward and inward (3). This results in a stretch injury and occasionally in a tear of the nerve. 


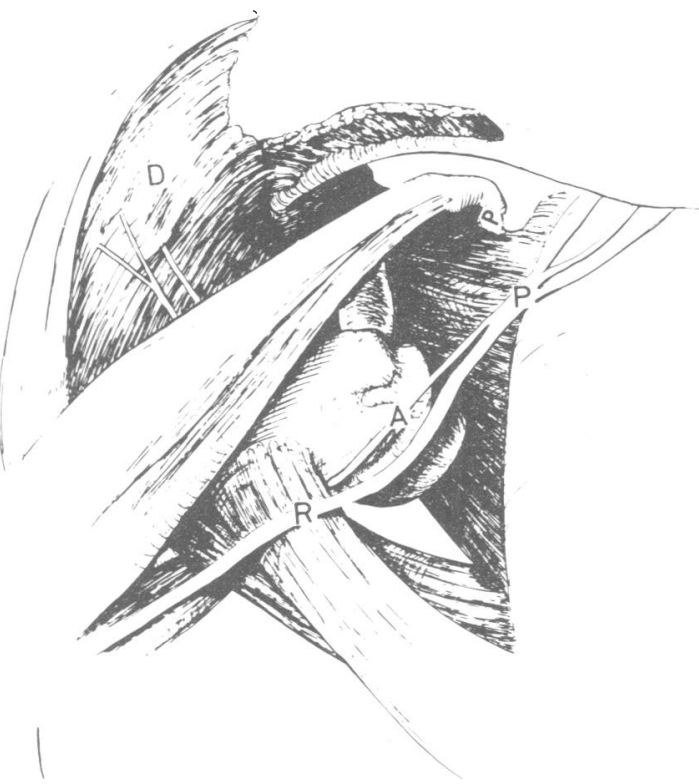

Fig 2 The head of the humerus is shown to be displaced anteriorly and inferiorly as in the commonest type of shoulder dislocation. This is often complicated by fracture (not shown). The axillary nerve and at times the radial nerve and posterior cord, are injured by the downward displacement.

deep surface of the anterior and intermediate fibres of the deltoid muscle by a series of short branches. The posterior division is shorter, may arise from an earlier branch to the teres minor muscle and it supplies the more posterior deltoid muscle fibres which arise from the spine of the scapula. ${ }^{7}$ The anatomical features are such that the nerve is only free for a short distance in the axilla and for the remainder of its length it becomes attached to the deltoid muscle by numerous branches. This appears to render it susceptible to stretch injury as in dislocation and local trauma. The injury is most commonly seen with fracture of the neck of the humerus or shoulder dislocation (fig 2) and in many of these patients, the nerve complication is probably undetected because it is mild in degree or because the joint or bony injuries dominate the clinical picture. Its occurrence after blunt shoulder trauma suggests that extreme scapular thoracic movement and shoulder displacement, with relative fixation of the proximal portion of the axillary nerve, posterior cord and brachial plexus, also can be a mechanism of injury.

\section{MANAGEMENT}

The degree of involvement of nerve function must be carefully assessed by clinical examination and it is important to detect any flicker of preserved muscle action. As has been noted, sensation may be normal in the presence of complete deltoid paralysis. When the palsy is incomplete by clinical examination, electrical tests are not essential; the nerve lesion can be said to be in continuity and some recovery can be expected. When the clinical paralysis appears to be complete, however, electromyographic examination should be undertaken.

It has been our general experience in the assessment of other nerve palsies, that about $15 \%$ of those palsies judged to be complete by clinical examination, will in fact be incomplete as evidenced by the finding of motor units under voluntary control on electromyographic examination. When motor units on volition are present, the lesion is in continuity and gradual improvement can be expected over a matter of a few months and up to about 12 months. A routine of daily shoulder exercises and movements should be prescribed as this prevents the troublesome and at times painful complication of fixation of the glenohumeral joint.

When the palsy is identified as complete by clinical and electromyographic criteria, follow-up examination should be done at intervals of about one month. The pace of recovery for the axillary nerve, as can be expected from the time re-innervation/ distance relationship, is such that there should be some recovery between the third and fourth month after onset. Evidence of re-innervation must be looked for and if nascent polyphasic potentials or motor units under voluntary control do not appear by about the fourth month, the lesion may be in discontinuity. Although the outcome was poor in the one patient who underwent surgical exploration and nerve grafting, this procedure offers the only hope for recovery of nerve and muscle function when the nerve is in discontinuity. With newer techniques of nerve repair with the use of the operating microscope, attention to the fascicular pattern and the use of nerve autographs, further assessment of the outcome of this approach is required.

The authors acknowledge the considerable assistance of Miss A Mrazek, RN in the examination of these patients and in the review of the data. We thank our collegues for referring their patients and we thank Dr AR Hudson for follow-up information and for the results of the surgical explorations. We are also thankful to Elizabeth Gilbert for the anatomical illustrations.

\section{References}

${ }^{1}$ Pollock LJ, Davis L. Peripheral nerve injuries. Chapter 1: Incidence. Am J Surg 1932a;15:179-81. 
2 Pollock LJ, Davis L. Peripheral nerve injuries. Chapter 26: The axillary nerve. Am J Surg 1932b;17:462-71.

${ }^{3}$ Frazier $\mathrm{CH}$, Silbert S. Observations in five hundred cases of injuries of the peripheral nerves at U.S.A. General Hospital No. 11. Surg Gynecol Obstet 1920;30:50.

${ }^{+}$Bristow WR. Injuries of peripheral nerves in two World Wars. Br J Surg 1947;34:333.

${ }^{5}$ Blom S, Dahlback LD. Nerve injuries in dislocations of the shoulder joint and fractures of the neck of the humerus. Acta Chir Scand 1970;136:461-6.

- Leffert RD, Seddon HJ. Intraclavicular brachial plexus lesions. J Bone Joint Surg 1965;47B:1:9-22.

7 Sunderland S. Nerve and nerve injuries. Edinburgh \& London: Livingstone, 1968.
' Parsonage MJ, Turner JW. Neuralgic amyotrophy; the shoulder girdle syndrome. Lancet 1948;254:973-8.

${ }^{9}$ Gathier JC, Bruyn GW. Neuralgic amyotrophy. In: Vinken PJ, ed. Handbook of Clinical Neurology. Amsterdam: North Holland Publishing Company, 1970. Part 11:8:77-85.

${ }^{10}$ Kirby JF, Kraft GH. Entrapment neuropathy of anterior branch of axillary nerve; report of case. Arch Phys Med Rehab 1972;53:383-7.

"Watson Jones R. Fractures and joint injuries. 4th edition. Vol 1. Edinburgh: Livingstone, 1952.

${ }^{12}$ Seddon HJ. Peripheral nerve injuries. Medical Research Council Report Series Number 282. Seddon HJ, ed. London: Her Majesty’s Stationery Office, 1954. 